\title{
PRICE STABILIZATION, 1950-1952: RETROSPECT AND PROSPECT
}

\author{
By David Ginsburg $\uparrow$
}

\begin{abstract}
"Price and other controls are often opposed out of fear that such measures will concentrate power in the Government and threaten our freedom. By inclination I, too, am opposed to Government controls. But the gravest threats to the preservation of the American system today are not Government controls. They are military defeat abroad and further inflation at home."
\end{abstract}

B. M. Baruch ${ }^{2}$

This article is concerned with some of the difficulties of preventing inflation and stabilizing prices in a time of rearmament for a limited emergency of unlimited duration. It deals particularly with one mistake and one perplexing problem.

The period immediately following Korea is used to demonstrate that efforts to increase production and indirect controls (measures designed to limit demand by higher taxes, more savings, restrictions on credit and the supply of money, and reduced government and private non-defense spending), although basic to the attack on inflation, must, when the emergency strikes, be supported immediately or even preceded by direct controls over prices and wages. The mistake, therefore, is the failure of the Government to use price and wage controls early enough to prevent harmful and unnecessary price increases in the Fall of 1950. The problem is to determine what kind of direct controls, if any, are needed for a continuing but partial mobilization.

The major underlying assumption is that the danger of further aggression from the Soviet Union will not abate soon.

Rapidly rising prices and living costs are fever signs in mobilizution. Those who produce military goods are paid for their work in wages, salaries and profits. The added dollars, if they are not saved, are sent to market to buy civilian goods and services the supply of

$\dagger$ General Counse1, Office of Price Administration and predecessor agencies, 19401943; Deputy Director, Economics Division, Office of Military Government in Germany. Member of the Washington, D.C., bar. Author of Legal Aspects of Price Control in the Defense Program, 27 A.B.A.J. 527 (1941); The Emergency Price Control Act of 1942: Basic Authority and Sanctions, 9 LAw \& ConTEMP. ProB. 22 (1942).

1. Hearings before Committee on Banking and Currency on S. 3936, 81st Cong, 2d Sess. 99 (1950). 
which has been reduced in order to satisfy defense needs. There is more money to spend than there are goods to buy.

Unless the mobilization is so leisurely as hardly to deserve the name, the obvious cure-to increase the production of items in short supply-is impractical; the resources even of our own cointry are limited. ${ }^{2}$ In the present mobilization nothing we could do in the near future to increase the supply of civilian goods and services could eliminate the "inflationary gap" between supply and demand. ${ }^{3}$ The danger of the gap is that prices will be "pulled" up by the bidding of buyers against each other for a limited supply of goods. When this happens wage-earners may demand and obtain higher pay in order to maintain their living standards. Prices will then be "pushed" up as a consequence of the pressure of wage and other cost increases so large that they cannot be absorbed through greater efficiency or lower profit margins. ${ }^{4}$ Higher wages also increase purchasing power. The

2. The Director of Defense Mobilization, Mr. Charles E. Wilson, has commented on the point in these terms:

"I have also been asked why I, a strong advocate of ever more and better production, have not come out for more production as the answer to inflation. The argument is that if we produce more to meet the rising demand, the supplies .will suffice to meet the requirements, and there would be no pressure in prices.

That argument holds water in normal times, but it's a sieve in abnormal times.

We simply do not have enongh materials to permit all-out production of durable civilian goods at the same time that we are striving to prodnce tanks, planes, and guin in sufficient numbers to deter Russia from an attack.

I have, however, supported additional production of basic materials such as steel, copper, and aluminum, as well as many other materials, as one means of meeting defense needs without too great a drain on the civilian economy. We are already beginning to achieve noteworthy increases in such production.

But this is a far cry from supporting all out production of durable civilian goods such as automobiles, refrigerators, TV sets and the like. Increased production in such lines is not the answer simply because it's impossible."

Charles E. Wilson, "I Hate Controls But We Need Them Now", N. Y. Times Magazine Section, August 26, 1951.

3. Director of Defense Mobilization, First Quarterly Report to the PresineNT 4 (April 1, 1951). The term "inflationary gap" is often encountered in discussions of economic stabilization. In its simplest conception it describes the excess of cash income available to consumers over current production available for purchase by consumers at existing price levels. "Inflationary pressures have a simple origin-more money seeking goods than there are goods to buy. The excess of demand over supply is the "inflationary gap." " DiREctor of Defense Mobilization, SECOND QUARTERLY Report to THE PRESIDENT 33 (July 1, 1951).

Roy Harrod demonstrated that the formula for measuring the amount of the inflationary gap comes to this: ". . . the excess of governmental expenditures and capital expenditures - taken together-over the amounts of money paid in taxes and the amounts of money normally saved, taken together." N. Y. Times, October 7, 1951, Magazine Section, "Inflation; A Primer for Today." Forecasts of the amount of inflationary gap are subject to correction to the extent that assumed expenditures and tax payments are different from the amounts actually expended and collected.

The conception is primarily useful as a rough yardstick for measuring anticipated inflationary pressures in some future period. When that period has passed it will, of course, appear that the gap was bridged, in part, by price increases and, for the rest, by savings.

4. Hart, Defense Without Inflation 59 (1951). 
reciprocal interaction of prices and wages-the price-wage spiralcan be started either by price increases which raise the cost of living and lead to wage increases, or by wage increases which raise the costs of production and lead to price increases. The greatest single danger from domestic sources which confronts the country today is the danger of spiraling inflation.

If fixed prices were the final object of government policy it would be simple to establish a controls program (although difficult to maintain it). But an unyielding price structure is not an end in itself. In mobilization, we seek substantial price stability, not absolute price inflexibility. We need stability for at least three reasons: to provide the most favorable conditions for defense production; to assure that the rewards and sacrifices of mobilization are distributed fairly; and to prevent avoidable increases in the permanent structure of costs, wages and prices.

The compelling need for increased defense production requires that doctrinaire adherence to an excessively rigid price and wage policy should not be allowed to disrupt that production or to destroy production incentives. By the same token a government in mobilization cannot tolerate the disorganization of markets and demoralization of workers caused by spurting price increases. Production which may be needed for survival flourishes only in an economic atmosphere in which buyers and sellers can plan future costs and prices with a measure of confidence. For this reason, in mobilization, controls over inventories, production and distribution, through priorities, allocations and related supply controls, must replace the free price or market system as the means for rechanneling material resources to defense purposes. The job cannot, with safety, be done otherwise. Goods and services needed for defense must go not to the highest bidder but where they are most needed. Priorities and allocation powers are essential. Without price stability these powers could not be effectively invoked.

Equity in the allocation of the rewards and sacrifices of mobilization is a fundamental objective which is translated into specific policies only with very great difficulty. There are no exact economic guides to equity unless, arbitrarily, they are derived from past relationships. In a mobilization designed for the long-pull (or what we are beginning to normalize by the softer phrase "defense economy") historic standards of equity rapidly lose their relevance, and equity comes to mean, in practice, a working balance among group interests, business, labor and agriculture, all of whose elements are persuaded that the balance is fair. 
Finally, unless the cost of living is stabilized, wages and production costs are bound to rise; and as the wage-price spiral accelerates, faith in the government's power and leadership is undermined. The entire economy, not the stabilization program alone, is then placed in jeopardy by loss of public confidence in the value of liquid assets and a mass flight from accumulated dollars into goods.

The risk of a runaway inflation is obviously greater if spiraling begins from a level already regarded as high.

\section{II}

In the seven months between June 25, 1950, and January 26, 1951-between the invasion of South Korea and the beginning of general price and wage control - the cost of living rose, on the average, nearly $1 \%$ per month; wholesale prices more than $2 \%$ per month; the prices of 28 sensitive primary market commodities (agricultural and industrial) more than $6 \%$ per month. Why did the Government delay so long before trying to stop the upward march by direct price control?

The price and wage increases which took place during these months are now imbedded, perhaps permanently, in the nation's cost structure. Would not the bolder policy of a quick temporary general price and wage ceiling-so long and persuasively advocated by $\mathrm{Mr}$. Baruch-have been a wiser policy from the viewpoint of the public interest?

Fully six months before Korea the President and his Council of Economic Advisers had told the country that the level of prices was already high enough to be generally profitable at a high level of activity, and that there was no justification for further broad advances. ${ }^{5}$ Immediately after Korea the Council reviewed what had happened to the economy since the end of World War II. ${ }^{6}$ It observed that in those five years we had experienced five different phases of business activity, including a bad postwar inflation (climaxed in 1948 by an all-time high in prices), a seven-month recession in 1949, and a recovery so swift that by January 1950 the Council had been obliged to warn that "every effort" should be made to avoid further price increases. Why was this warning ignored in the fall of 1950 ?

In 1942 the monthly average of the wholesale price index for all commodities $(1926=100)$ had been 98.8 . In 1945 it was at

5. Council of Economic Advisers, The Annual Economic Review 99-100 (January 1950).

6. Council of Economic Advisers, The Economic Situation at Midyear 1950, pp. 25-37. 
105.8. The index in June 1950 was up to 157.3 ; by March 1951 it had reached 184.

In 1942 the monthly average of the cost-of-living index (consumers' prices; $1935-39=100$ ) had been 116.6. In 1945 it was at 128.6. The index on June 15, 1950, was up to 170.2 ; by March 15, 1951, it had reached 184.5 .

Measured not by index points but in terms of percentages, from Korea to the beginning of general price and wage controls, wholesale prices advanced $14.5 \%$; sensitive primary market commodities $45.8 \%$; and the cost of living $6.6 \%$. On November 15, 1951, the cost of living was $10.8 \%$ above the pre-Korean level.

Coming at a time when the level of business activity in most industries was high, and the level of prices only slightly below post-war peaks, the invasion in June 1950 set off a spurt of consumer and business buying which resulted almost immediately in abrupt price increases. Before the first wave had fully subsided, the news of the mass Chinese intervention in late November set off a second wave of buying which carried prices to new highs in mid-February 1951.

The increased prices exacted during this period were mostly speculative and unjustified. Demand was financed by accumulated liquid assets and credit expansion, not by sudden increases in buying power resulting from defense spending or Government deficits. Consumer goods and services were still in plentiful supply. For nearly seven months, therefore, businessmen built their inventories and plants, and consumers manifested in the market their anticipations of future shortages and price increases-and thus, in large measure, brought about with their fears the very conditions against which they sought to insure themselves.

\section{III}

Three weeks after the Korean outbreak the President sent a special message to the Congress outlining an emergency legislative program to permit industrial mobilization and to curb inflation. $\mathrm{He}$ did not ask for power to control prices and wages. A week later the President restated his views in the mid-year economic report to the Congress. He directed attention to the "marked rise" in prices (spot index for 28 commodities up $10 \%$, wholesale prices up $3.7 \%$, the cost of living up $1.4 \%$ ) but limited his legislative proposals to higher tax rates (a $\$ 5$ billion increase) and powers to regulate consumer and mortgage credit, to limit commodity speculation, to issue priority, allocation and related orders over supplies and facilities, and to expedite the production of essential goods by Government loans 
and other incentives. Inexplicably, in view of the tenor of his report, he did not ask for even standby authority to control prices and wages. The President simply stated that we should rely in major degree upon fiscal and credit measures and added:

"The more prompt and vigorous we are with these general measures, the less need there will be for all of the comprehensive direct controls which involve the consideration of thousands of individual situations and thus involve infinitely greater administrative difficulties and much greater interference with individual choice and initiative." 7

By September 1 the Congress had compromised its differences on the Defense Production Act of 1950 . The final version not only gave the President most of the production and supply powers he had sought but in Title IV gave him authority to control prices and wages. For this unprecedented legislative bonus he was largely indebted to Mr. Baruch.

It is doubtful, of course, whether every vote for the bill represented a moral commitment to the principle of price stabilization. Some probably sought to give the majority party a choice between responsibility for permitting inflation and the onus of an unpopular controls apparatus. It may be, too, that the President refrained from asking for price and wage controls because he believed that in this way the authority would be granted more readily. All this seems immaterial. The essential fact is that a reasonably adequate law ${ }^{8}$ was placed on the books in the record time of something more than six weeks. For this action the Congress deserves credit.

Nearly five months passed before those powers were used. For the consequences of this inaction the Executive must take responsibility.

Meanwhile, all Washington set about as if deliberately to recreate for the country the mood, the tensions and the anxieties of World War II. A system of priorities and allocations was promptly established-and a more stringent controlled materials plan just as promptly forecast. Hope was expressed that credit controls and increased taxation would suffice to control inflation-but warnings repeatedly were broadcast that price controls would be invoked if necessary. Brownouts were predicted. Export controls were tightened. Industry committees were established; anti-trust laws were reexamined. An excess profits tax law was enacted. The draft was debated. Wholesale prices reached a new high. A steel shortage was forecast. Government

7. U.S. President, The Mrdyear Economic Report 10 (July 1950).

8. See Field, Economic Stabilization under the Defense Production Act of 1950, 64 Harv. L. Rev. 1-26 (1950). 
stockpiling was accelerated. Power expansion was called for. An Economic Stabilization Agency was created. Canada and the United States joined in plans to coordinate their economies for defense. A Wage Stabilization Board was organized. The Chairman of the National Security Resources Board warned that unjustified price increases would be taken into account if and when the Government established price controls. Earlier he had said that the country was moving from a "light grey" mobilization into one of darker hue-and that the "closer we come to full mobilization the more likely wage and price controls are." In his maiden address Mr. Alan Valentine, the first Administrator of the Economic Stabilization Agency (ESA) stressed the differences between World War II days and the postKorean period, emphasizing that direct controls only restrict or postpone or conceal the effects of inflation without curing it. "We must place our first hope in indirect controls which in general must be our first effort." Michael V. DiSalle, the Mayor of Toledo, became price administrator; "informed sources" said that this brought direct stabilization action nearer. But the same sources also felt certain that no direct wage or price control program would be started until a staff had been recruited. Recruitment was slow. ${ }^{9}$

It is difficult now to describe the near hysteria of this strange seven month period. As a nation, we were reacting to the facts of 1950 with the fears and impulses of 1944 . We listened to the North Korean rifle fire on the 38th Parallel-and heard Soviet bombs, mostly atomic, exploding over Washington and New York. Economically, it was blindman's buff after two double martinis. It was inflation without any substantial increase in defense spending and despite a more than adequate supply of consumer goods and services.

The formal announcement of the government's intention to impose mandatory general price and wage controls came December 15, 1950, in the President's declaration of the existence of a national emergency. Administrative preparations for this step were made during December and January. ${ }^{10}$ As a stop-gap, voluntary restraint was called for and a set of voluntary pricing standards published. In addition, telegrams were sent to several hundred leading concerns asking them to cooperate with the government's stabilization program by not increasing prices except after seven days notice.

In the President's economic report to the Congress on January 12, 1951 , it was made clear that events had overcome official inhibitions.

9. See BNA, Daily Report for Executives, Nos. 139-233 (1950).

10. Council of Economic Advisers, The Economic Situdition at Miduear 1951, p. 41. 
"We must use direct controls," said the President, "as well as [these] tax and credit measures in order to deal with the problem of inflation. - . . This will require the broad extension of price and wage controls to hold down the upward spiral." 11

Wholesale prices generally had by then increased $11 \%$ over their pre-Korean levels and many important items had risen far more than the average. Chemicals, for example, had risen $211 / 2 \%$; textiles, $24 \%$. The cost of living had already moved up 41/2\% over June 1950. Wage increases, as might be expected, were widespread and substantial. After September 1950, according to the Council of Economic Advisers, a "landslide movement developed" for higher wages, accompanied in some instances by demands for fringe benefits. Increases in wage rates were often followed by price increases. Price increases encouraged demands for wage increases.

The first significant action to control prices was not taken until January 26, 1951, when Mr. DiSalle for the Office of Price Stabilization issued the General Ceiling Price Regulation (GCPR). In effect, this established a ceiling over most commodity prices-the exemptions related largely to specified farm products-at the highest levels at which each seller had made deliveries during the five week period from December 19, 1950, through January 25, 1951. A simultaneous parallel order stopping further increases in wages was issued by the new ESA Administrator, Mr. Eric Johnston.

By this time any normal balance or relationship among prices and between prices and wages, over the economy as a whole, had been utterly destroyed. The cost structure of the country had become a crazy quilt of prices and wages which reflected the hopes and fearsthe patriotism and the cupidity-of each seller as he reacted to the daily cascade of rumors, statements, entreaties, and forecasts which had poured out of Washington during the previous five months. All of these imbalances and inequities, for the time being at least, were frozen into a price structure which, from the viewpoint of government administration, could only be described as a price controller's nightmare. Sellers and buyers, moreover, were taught an unforgettable lesson of the kind that Pangloss taught Candide. Sellers who heeded their government and exercised a decent restraint in pricing policies were penalized by having their relatively low prices made into legal ceilings. Less scrupulous competitors who either ignored or defied the government's hesitant efforts to stabilize prices by voluntary means profited by having their high prices accepted as the lawful maximums. Buyers who abided by repeated promises that prices would soon be

11. U.S. President, The Economic Report of the President 18-19 (January 1951). 
stabilized and then rolled back (either to pre-Korea levels or to October 15 levels or even to the levels which they had reached on December 15) found themselves with short supplies in a rising market. Hoarders and speculators, however, benefited enormously. At the last moment, it seems, the government decided to have no price roll-backs of any kind. Prior to that time Mr. DiSalle had been repeatedly quoted in the daily press as favoring the principle of roll-backs. Yet with GCPR, the legal maximum became the highest price at which any seller had delivered his goods or services in a five week period which included the Christmas rush and the climax of the post-Korea buying panic.

Who was responsible for that decision is no longer important. What may be important is that future generations of price controllers, if the breed survives in public service, had by this nearsighted and cynical act been permanently deprived of any'moral basis for seeking price restraint through appeals for voluntary self-limitation.

IV

The cost of the delay in establishing price and wage control was very great. In human terms, hardest hit were the four million pensioners under Social Security; nearly as many veterans drawing benefits for retirement or disability; government workers-about $61 / 2$ million of them-in federal, state and local jobs; retired federal workers, retired railroad workers, and their widows; investors in bonds, mortgages and annuities; other fixed income groups; and most unorganized workers.

To the government the cost could be measured in dollars, in price tensions, in time, and in the loss of public confidence in its promises. Before the Congress adjourns for the nominating conventions in the summer of 1952 it will have appropriated a minimum of $\$ 150$ billion for post-Korea foreign aid, defense and rearmament. Price increases since June 1950 have added about 20\% to the military bill for weapons and at least $\$ 20$ billion to the cost of consumer goods and services in 1951 alone. $^{12}$ Of very great importance, the leeway which existed in the price structure (taut though it already was in January 1950)-the leeway which permits some price increases, yet gives the government time to think and act before the risk of dangerous inflation is confronted - was unwisely dissipated in speculative excesses, leaving far less elasticity and discretion for price policy in the event of war or worsened international relations.

The failure to stabilize prices and wages in the last half of 1950 also cost months in terms of the defense program. We sold the oppor-

12. See testimony of Defense Secretary Lovett and Secretary of the Army Pace, June 7,1951 , before the Sub-Committee of the Senate Committee on Appropriations. 
tunity to convert speedily to defense production for a windfall (of civilian goods) and a shortfall (of military goods). We were be= trayed into an easy prosperity when we should have been hard at work mobilizing. The exact time lost cannot be measured, but the controlling forces are clear enough. What incentive was there for businessmen to seek military orders, to convert to arms production, to comply with the spirit of defense supply regulations, or to press the defense establishment to clarify the rearmament program, when the prices of civilian goods-and profits-were soaring to unprecedented heights? How much of the slippage in military production schedules, of which $\mathrm{Mr}$. Wilson speaks, ${ }^{13}$ was due to the magnetic attraction of more profitable operations elsewhere?

\section{V}

Within the government there were two reasons, explicitly stated and more popular than others, for the reluctance to establish ceilings over prices and wages. In the first months following Korea we were told that the inflationary pressures likely to be generated by a small defense program could almost certainly be managed by taxation and other indirect controls. Early military successes and a brief halt in the upward march of prices, before the Chinese intervention in force, gave some early support to this view. Later, as prices nevertheless rose because of military reversals and speculative and psychological forces, it was suggested that action must be delayed for lack of a properly organized government agency to administer the controls. At a much later stage an argument by way of afterthought crept in. Rising prices and the postponement of controls, it was said, had stimulated the production of civilian goods and services thus creating a large "civilian reserve" which would be most useful when cut-backs were required to speed defense production. ${ }^{\mathbf{1 4}}$

13. Director of Defense Mobilization, Third Quarterly Report to The PresiDENT 6 (October 1, 1951). The major semantic contributions of the present defense emergency are the words "slippage" and "shortfall." They have apparently been found helpful in describing the failure to meet established production schedules. I have not tried to learn whether the words are of recent coinage or whether they were first minted in World War II and are only now being widely circulated.

14. The argument is almost certainly fallacious. Given raw materials and no government restrictions the production would have been forthcoming at existing prices which, as the government itself stated in January 1950, were already high enough to be generally profitable at a high level of activity. Equally important, the price increases which occurred in the fall of 1950 largely benefited those industries which competed most directly for materials required in the defense program and which produced goods the demand for which could most readily be postponed. The enormous quantities of television sets, radios, and most other consumer durables manufactured in the fall and winter of 1950 benefited neither the government nor those industries, nor did they create the kind of "civilian reserve" which is useful in time of emergency. The race for production resulted in grossly unbalanced inventories and windfall profits to the detriment of the defense program. 
Underlying the main surface contentions, for most people, were others which revealed deep uncertainties regarding the merit, the feasibility and the political wisdom of seeking to establish emergency ceiling controls in a defense economy. It was said that direct controls are hard to administer and enforce; that they are rigid, tend to freeze price relationships and narrow the choice of buyers. It was said that indirect inflation controls-increased taxation and savings and limitations on the extension of credit-interfere less with individual liberties than direct controls, and preserve a wider area for individual choice and the play of free market forces. There was widespread discussion of the fact that, increased civilian production apart, measures designed to siphon off and reduce the pressures of excess demand, particularly taxation, are the only permanent cures for inflation; that price controls, to a considerable degree, are merely palliatives. Some also felt that since price and wage controls had been dropped by the government only a few years earlier an administration which restored them might suffer politically.

These observations had merit. But they still left a responsible government with the obligation to decide whether indirect controls alone could stabilize the economy and, if so, whether such controls could be made effective fast enough to avoid a damaging inflation. The greater political risk, moreover, was not the possible unpopularity of controls but that uncontrolled price rises would cause serious harm to large elements of the population.

The first major contention of those responsible for delaying direct price action was that the foreseeable size of the defense program made ceiling controls unnecessary. The contention was defective in that the impact of mobilization on the country did not depend solely on the size of the program. In part it depended on what people thought and feared and how they reacted to the threat of another war; in part on whether (as in World War II) increased production needed for defense could be obtained by putting unused resources-unemployed men and facilities-to work. In the fall of 1950 there were few idle resources, so that any sizeable rearmament program was bound to require cutbacks in normal peacetime production. Popular instincts, too, were sounder than economic forecasts. Buyers were not persuaded by a government policy which seemed to say that, for purposes of economic mobilization, Korea was a minor police action which could be supported by the overflow from our vast economic larder, but from the viewpoint of international political relations it was a grave crisis in world affairs which gave rise to the imminent danger of a third world war. The people generally understood that in Korea the Soviet 
Union had deliberately resorted to war in the service of aggression; that in Korea our country and its United Nations allies were defending against Soviet military power scantily clad in satellite flags; that such a war was a major war; that it could readily preface the final holocaust. More than 100,000 casualties and much more than $\$ 100$ billion now prove that popular instincts were as right in the fall of 1950 as in the summer of 1941 when in Washington only President Roosevelt, Mr. Baruch and a handful of others were deeply committed to a vastly enlarged defense program. Popular prevision undoubtedly hastened the onset of serious inflationary pressures, but it was not myopic.

The second main defense of those who chose to temporize with ceiling controls was the lack of staff and the difficulties of recruitment. The defense fails because the shortage of personnel, like other shortages in this period, was in large measure caused by and could have been averted by government action.

Certainly controls over prices and wages would soon become futile or intolerable without an adequately staffed agency to administer them. It is also true that it is increasingly difficult to persuade men of capacity to forego the independence and rewards of private life for the diminishing satisfactions and the hazards of government employment. Yet in time of emergency public service is a duty; and, as a people, we have never failed to respond to the bugle. This time, although some listened, not even a whistle was heard.

While deliberately allying itself with and even encouraging hostile attitudes toward price and wage controls, the government simultaneously sought to recruit men to plan-not to administer or enforce but merely to plan-such controls if they should be needed. Veterans of OPA were not expressly disqualified by reason of their experience although businessmen and seasoned public officials were obviously, and understandably, preferred for the more prominent posts. But to induce responsible businessmen to abandon their work, leave their homes, and enter government service, to draft paper plans for distasteful controls for possible use in an emergency which might never arise-would have required not persuasion but hypnotism.

When the President declared the existence of an emergency on December 15, 1950, the parent agency for all economic stabilization matters, ESA, had a total of 225 employees. Forty-five days after the establishment of general price and wage controls the subsidiary price agency alone, OPS, had 4158 employees and 90 offices throughout the country. For this extraordinary accomplishment great credit is due Mr. DiSalle. The obvious lesson would seem to be that in emergency the government must take the risk of necessary action; if it does, the 
personnel to administer the laws and regulations can be drafted from private life, from enterprises subject to control, and from the ranks of government itself. A collateral observation is that the government gains little from joining its critics in stigmatizing controls on which it may later be forced to rely.

\section{VI}

The alternative to the government's irresolute efforts lay in some adaptation of the Baruch Plan. It is a plan for industrial mobilization designed to prevent inflation by stopping it. In its stabilization aspects, the Plan calls for a general ceiling over all prices, wages and other elements of cost, as part of a broader program which makes maximum use of taxes and other indirect controls. Inflation control, in turn, is coupled with an encompassing system of priorities and allocations. The critical stabilization element is the general ceiling which, unlike taxes and other indirect controls, can be put into instant operation with immediate effect when the need arises. ${ }^{15}$

The strategy of price stabilization in the fall of 1950 seemed to call for initial reliance on voluntary appeals, together with a request to Congress for higher taxes and other indirect controls; ceiling price and wage controls were to be used, if at all, only as a last resort. ${ }^{16}$ What was needed instead were prompt measures to prevent unnecessary price and wage increases until such time as programs for higher taxes, increased savings and stringent credit controls could be enacted or put into effect. The strategy failed because the order of necessary action was reversed.

Can it be doubted that the country would have united behind the Administration if it had stood for the following plan to prevent inflation?

Step One: Immediately after Korea, the President

(a) declares the existence of an emergency, calls for a temporary halt to price and wage increases, and clearly explains to the country why this measure of voluntary restraint is essential;

15. See statement of Bernard M. Baruch, July 26, 1950, Hearings, supra note 1, at $97-104$.

16. The term "indirect," in the phrase "indirect controls," offers an interesting problem in the meaning of words. To many people it seems to convey the notion of "easy." The truth is that the so-called "indirect" controls are as direct as "direct" controls and no less painful and burdensome. The basic difference has to do with governmental machinery. Indirect controls are administered by the Federal Reserve Board and the Bureau of Internal Revenue; price and wage controls require a new government organization. But there is nothing "indirect" about the bite of the individual income tax; it hurts. 
(b) orders the establishment of a uniform government purchase and resale program for imported raw materials essential to defense production and the beginning of negotiations for a multi-lateral international allocation and price agreement program for such commodities;

(c) creates an Economic Stabilization Agency to formulate and issue voluntary standards for price and wage stabilization and to arrange for the necessary minimum record keeping;

(d) transfers to ESA, on a temporary emergency basis, the stabilization planning group of the National Security Resources Board, and selected volunteers from other government departments and agencies who have either had experience in stabilization work during the last war or who are otherwise familiar with price and wage problems;

(e) sends a message to the Congress reporting what he has done and asking authority to establish legally enforceable price and wage ceilings and pay limited import subsidies as part of a larger program of emergency legislation covering priorities and allocations, as well as increased taxation and other indirect antiinflation measures.

Step Two: Immediately after the Congress has acted the ESA

(a) promulgates a temporary general price and wage ceiling and promptly thereafter begins the work of adjusting it for long term contracts, seasonal requirements and related factors and then replacing the general ceiling with more enforceable regulations tailored to the requirements of each industry, beginning with producers and manufacturers, and

(b) formulates standards for relief and decontrol in harmony with a defense economy in which stabilization is to be insured by a balanced program of both direct and indirect controls.

The failure of price policy in the fall of 1950 was the failure to recognize soon enough that in a defense economy under conditions of high level employment indirect inflation controls are essential but insufficient. To decry direct controls for the limited emergency of 1950 and to endorse them for an all-out war is to assume that the forces of inflation are responsive to descriptive adjectives. The fundamental question in each case is not whether the emergency is absolute but whether in the absence of direct controls the going economy can support the required degree of mobilization, physically and psychologically, without a dangerous rise in prices. To justify the reluctance to invoke the controls by saying that it was hard to foretell when spiraling inflation might develop is to evade the critical point. The question is 
not one of timing but of function. There are some circumstances in which only direct controls can be effective; there are some jobs that indirect controls cannot do.

First: Indirect controls cannot cope with intense, temporary price pressures which arise from psychological and speculative forces. Such pressures readily develop in an economy characterized by high levels of activity and a large volume of accumulated liquid assets.

The immediate post-Korean inflation was caused in large part by the expectation of future price increases and shortages. The modest program of indirect controls recommended and adopted did not stop unwarranted price increases; indirect controls could not have stopped them without subjecting the economy to strains and risks greater than the inflation itself.

To have prevented the two waves of buying and price increases which developed in the last half of 1950 would have taken tax rates so high and credit controls so drastic that no free nation would conceivably adopt them for defense or war. Even if enacted, controls of such severity would have been hurtful and dangerous after the immediate crisis had passed. The Federal Reserve Board can turn credit controls on and off with reasonable celerity; but taxation, at least in the present division of government power between the Congress and the President, cannot be so administered. ${ }^{17}$

Those who urge that speculative excesses on particular commodities should be disregarded because offset by subsequent periods of liquidation are misled. In business it is only partly true that what goes up must come down. The enormous post-Korean price increases in wool, rubber and similar commodities were almost all wiped out by late 1951. But price peaks for industrial commodities (e.g., steel) are not so easily cut down. Higher costs become lodged in the industrial price structure and normally remain there even in the face of severely declining demand. Wage rates are among the most rigid of these elements. If wage rates are increased in periods of speculative demand they become, for all practical purposes, part of the industry's permanent cost structure. Only direct controls, which prevent speculative booms from having their effect on prices, can avoid this problem. Moreover, direct general price controls are essential to allay the fear of further price increases which is the greatest stimulus to speculative buying.

17. A partial solution might lie in tax legislation which provides for increased rates to become automatically effective at specified future dates. As a practical political matter Congress could far more readily postpone unnecessary step-ups as the effective dates approached than pass new tax bills as the danger of inflation became clearer. See Hart, Problems in Federal Finance, Current Business Studies, November, 1951, p. 19 (Trade and Industry Law Institute). 
Second: Indirect controls cannot stop the wage-price spiral without jeopardizing the objectives of the defense economy. Higher wage rates won by organized labor in periods of full employment not only raise costs-providing a justification or pretext, as the case may be, for raising prices-but increase spending power and demand so that higher sales prices can be exacted. Indirect controls diminish inflationary pressures not by limiting prices but by reducing demand; sellers cannot raise prices when buyers withdraw from the market for lack of spending power. Taxes, for example, take purchasing power from consumers, and credit controls make it difficult for businessmen or consumers to buy goods except out of savings or current income. Indirect controls thus stop the wage-price spiral by reducing the demand for goods (reducing sales) to the point where employers cannot afford to pay higher wage rates, and by reducing the demand for manpower (reducing employment) to the point where union leaders and workers will not risk strikes to get wage increases. Indirect controls break into the wage-price spiral by reducing the total volume-and the total profitability - of business operations.

Even if we had the Spartan political fortitude to use indirect controls in this manner, exclusive reliance on them might be disastrous. It would unquestionably involve a waste of resources through reduced employment; it might well deny the inducements necessary for essential defense expansion.

Third: Indirect controls in the form of tax rates high enough to restrain inflation create serious problems of taxpayer inequities, administrative difficulties, and weakened incentives to business.

To a low-paid white collar worker who has received no wage increase in the last year, a tax increase designed to control an inflation that has already impoverished him is neither a public service nor a source of relief. Following Korea the President called for a total tax increase of $\$ 15$ billion as part of a revenue and stabilization program which would be supported both by direct controls and indirect controls other than taxation. The Congress enacted about half of the recommended tax program, and influential members of both the Senate and the House have since warned that the tax limit, at least for a defense economy, is in sight or has been reached. To have prevented the price rises which began in the third quarter of 1950, without direct controls, would have taken increased personal taxes of at least $\$ 14$ billion (the increase in the annual rate of consumer expenditures from the second to the third quarter). Even this would probably not have sufficed since some increased demand would have been financed by savings and higher wages. The Congress in fact increased personal 
taxes not by $\$ 14$ billion but by $\$ 6$ billion. Contrary to those who would rely exclusively on indirect controls, the political truth seems to be that effective direct price and wage controls are needed to make higher taxes possible. The logic of this may not be wholly clear but it represents current political-and very human-realities.

As tax rates rise the pressure of powerful groups to obtain favored treatment in the terms of the tax laws and in their administration becomes a major problem of government. These pressures are enormously intensified when the government chooses to forego all reliance on direct controls-as it did immediately after Korea-and look exclusively to higher and higher levels of taxation to avert destructive inflation. Favoritism, government by pressure groups, and corruption are the inevitable by-products.

Reliance on taxes to hold prices down must confront an interesting paradox: Since increased taxes reduce the amount of disposable income they, therefore, reduce the demand-pull on prices. But since increased income taxes are persistently viewed by businessmen as equivalent to increased costs (which economically they are not) they tend to increase the cost-push pressure on prices. Even if there is no increase in current incomes, accumulated savings and liquid assets are available to pay higher prices if the current psychology so dictates.

There is a final danger that tax rates high enough to restrain inflation might seriously dull incentives to work and to assume business risks. It is questionable whether increases of the magnitude sought by the President would be high enough to make this danger significant. But tax rates high enough to stabilize a war economy might very well bring about this problem.

Fourth: Indirect controls cannot protect the government-and the taxpayer-against hold-up prices for essential defense materials. As military demands for weapons and supplies become imperative, prices rise for metals, chemicals, machine tools and other strategic defense items. This is true even in the unlikely event that taxes and credit controls are so speedily applied and so immediately effective that they not only stabilize but force down the prices of less essential and less strategic commodities and thus prevent a rise in the general level of prices.

Rising prices in turn encourage users to accumulate unnecessary inventories, and sellers to withhold goods in order to obtain further price advances. To enforce vitally needed supply and inventory controls in the face of the expectation of exorbitant profits would be extremely difficult even in the midst of war. In a defense economy, in practice, it would be impossible. Priority and allocation controls are 
simply means of managing and creating scarcities; they cannot be administered effectively without the support of price and wage controls.

Is it wise, however, to limit price increases on essential defense materials? Would not uncontrolled price rises on such items better serve the public interest by providing powerful incentives to maximize production, discourage non-essential consumption, and speed the search for substitute materials? Some price increases, we know, do call forth increased production. But without price ceilings sellers of essential commodities in time of emergency can exact prices so high that they far exceed any inducement to more production and merely represent economic blackmail. Beyond some moderate point, price increases for strategic commodities enrich the lucky producers and penalize those who happen to be engaged in the production of other goods. The cost of a small increment to defense production-which could in any event be obtained by other means-thus becomes an explosive combination of profiteering and distress.

The actual cost is even higher. Not only the price structure, but the wage structure is distorted. Producers of essential items, if prices remain uncontrolled, are economically free to increase wages to attract additional workers. Rising wage rates in strategic industries create irresistible pressures for wage increases in the rest of the economy, dragging the entire cost and price structure upward. Spiraling inflation can then be averted only by ever rising tax rates and stronger credit controls, creating more and more unemployment. ${ }^{18}$

\section{VII}

Quite simply, Mr. Baruch was right. However, now that power to control prices and wages exists and has been exercised, are we also equipped with the kinds of standards and policies which will enable us to endure the long and restless twilight period of no all-out war but no peace? How does this mischievous defense economy differ from the economy of war?

It differs first in objectives. We are not mobilizing totally but partially, and we have two main objectives: to create as soon as possible sufficient military strength to deter any potential aggressor, particularly the Soviet Union; and to build a base of economic strength and mobilized resources on which, if war should come, a massive total effort could quickly be mounted. We seek to restore our military

18. For portions of the analysis in this section I am particularly indebted to a speech by Mr. Gardner Ackley, Economic Adviser, OPS, before the Toledo Bar Association, October 19, 1951. 
productive capacity while maintaining a substantial part of our civilian industry in operation. ${ }^{19}$

It differs also in pace. The peak of the present mobilization program will not be reached before 1953, and it may be delayed beyond that. By late 1951 we had trebled the rate of our pre-Korean military outlays and were spending for defense at an annual rate of more than $\$ 40$ billion. This rate was scheduled to rise to $\$ 50$ billion by early 1952 and to $\$ 60$ or $\$ 65$ billion by the fall of that year. The increase is from about $13 \%$ of our national product in late 1951 to about $20 \%$ at the anticipated peak. This compares with $45 \%$ of our total output taken by the military at the height of World War II.

The pace of mobilization, although rapid, is further distinguishable from a war effort in that it is designed to be sustainable over a long period of time. A defense economy has no clearly foreseeable end. We are not trying to defeat an enemy in the field, but to reestablish and maintain a military power balance with a permanently hostile dictatorship. The graphic profile of the present defense program is sometimes described as a hump-a rise to a rounded peak followed by a downturn to a level somewhat below the highest point of the curve, at which it flattens out. After the hump is passed, it is often said, we shall settle down, indefinitely, to a plateau of defense expenditure, estimated at about 40 to 50 billion dollars annually. This is optimistic; the hump is more likely to be succeeded not by a plateau but by a gentle upward climb which will continue so long as Soviet imperialist ambitions remain uncurbed. The Soviet response-which at least we must match-will not remain static. And weapons of modern war rapidly become obsolescent; they must be replaced, usually at higher costs.

When heavy military outlays reflect not the short-term emergency of war but a long-term program for defense, unique price problems are posed. For the effort which is total and brief we can tolerate much more than for the effort which is partial and prolonged. In war, the future is hostage to the present for the single goal is survival. Defense, however, has no termination date. For this reason, we cannot for long defer the maintenance and indeed the expansion of our productive plant and equipment; we cannot for long permit our economy to be weakened by failure to maintain and replace necessary consumer goods; nor can we risk destroying the fertile source of our economic growth by failing to encourage new ideas, new products, and the establishment of new business firms.

19. Director of Defense Mobiluzatton, Third Quarterly Report to the President (October 1, 1951), p. 3. 
In a war economy the price controllers have the support, by and large, of a people committed to a fight for survival; in a defense economy they must do without the binding spirit of national unity and strong patriotic incentives to compliance. In World War II a balance of interests was achieved among the great economic groups of our economy; businessmen, workers and farmers-each made sacrifices recognizing that roughly equivalent sacrifices were required of all. Today, there is not only continued concern with the maintenance of relative economic positions, but there is no moratorium in the struggle of each group to improve its economic position relative to the others.

When we failed to grasp the nettle of controls in the fall of 1950 we permitted the precarious balance established by the free market to be upset, and thus far we have been unable to achieve another. Increased profits coupled with the growing strength of labor unions and the sharp rivalry among union leaders will be stumbling blocks to the restoration of any new balance. Inevitably, therefore, wage claims will remain an important factor in keeping the cost-push pressure on prices. These claims will be based primarily on higher living costs but, varying from industry to industry, they will also rely on increased workers' productivity and the growth of industry earnings. The government's proposal to force business to absorb increased wage (and material) costs out of profits will not be easy to enforce, even for those industries where the "industry earnings standard" can fairly be invoked. $^{20}$ Unless the cost of living is stabilized, government wage standards are far more likely to succumb to a tacit and powerful alliance of business and union leaders than survive as arbiters in the public interest of business and union differences.

In war the demand of the military largely controls the production machine; in a more limited emergency the tastes and desires of civilians remain highly important. Today more than four-fifths of our production is being used by civilians.

20. Eric Johnston, ESA Administrator, Strong Dollars 23 (November 30 , 1951). ". . . in addition to all other safeguards adopted by OPS against unwarranted severity in the regulations, every industry should have a definite minimum protection against fixed ceilings that would unduly impair its average profits position as a result of cost increases.

"Consequently, the so-called industry earnings standard was developed to fit that need for minimum protection to business. Under this standard, the prices in any industry can on its application be increased whenever its average return on net worth falls below 85 percent of the average for the three best years from 1946 through 1949-the base period then specified for the excess profits tax. The earnings standard is not designed as a profit control. It is an assurance to business against ceiling prices set too low to allow a fair and equitable return on operations." For a fuller statement of Mr. Johnston's policy guide for cost absorption, given to the Office of Price Stabilization on April 21, 1951, see DIRECTOR of DefFense MOBnIzation, Second Quarterly Report to the President 40-41 (July 1, 1951). 
The impact of war on the economy is general; the impact of defense mobilization varied. Wage increases in a war economy are almost always reflected to some degree in ceiling price adjustments; this is less true in a defense economy where profits are more dependent on normal civilian business. Today prices of metals, chemicals and machinery are pressing hard against ceiling controls; however, the prices of some foods, most textiles, and many items of consumer durable goods are below ceiling.

In war intense inflationary pressures develop and remain nearly constant; in a defense economy the pressures vary. The reasons lie in the nature of a partial mobilization. First, a defense economy is marked by humps in the levels of spending. We expect to reach the peak of our first hump in 1953; others may develop in years ahead as changes occur in military techniques or in the nature of our potential war needs. Second, in a defense economy inflationary pressures may ease as increased civilian supply becomes available but suddenly grow intense because of underlying explosive psychological factors. If it should become necessary to break the stalemate in Korea by force; if the communists should suddenly come to power in Iran; if Berlin or Vienna should be seized or blockaded, or Yugoslavia invaded, who can predict the resulting pressures on prices? In conditions of high employment, widespread availability of liquid assets and full utilization of resources, speculative booms based on the fear of war, the uncertainty of supply, or the anticipation of inflation can create serious danger of runaway prices. The collapse of such booms may be followed by periods of inventory liquidation and depressed consumer demand. Third, the inflationary pressures of a defense economy are altered as we rechannel our resources from old into new patterns of production. Pressures on certain prices become greater when we expand rapidly to meet specific shortages than when we continue unchanged an existing pattern of production.

\section{VIII}

There are some who recognize that direct controls are essential in an economy organized for war but who believe that in a defense economy the work of price stabilization can or should be done by indirect controls alone. The reasons why this is impossible with even a moderate degree of economic security have already been stated. Indirect controls are impotent to deal with panic forces; they give rise, in their more intense forms, to corrosive problems of government administration and weakened incentives to business; they cannot protect the government against exorbitant prices for essential defense materials; and, most pertinently for the economy of today, they cannot 
stop the wage-price spiral without jeopardizing the objectives of the defense economy.

Not only are indirect controls by their very nature incapable of providing stability, but existing legal and political limitations on their use in practice reduce even their theoretical effectiveness. We have been warned by Congressional leaders that the political limit of taxation in a defense economy has very nearly been reached. Revenue laws may be improved and loop-holes closed, but the basic structure of rates is not likely to be revised upward, at any rate not in an election year and not without great strain in any succeeding year since the burden of future increases in taxation is almost certain to fall on lower and, to a lesser degree, middle income groups. In extending the Defense Production Act, moreover, the Congress imposed specific limitations on the use of credit controls. Under the law as it stands today, the government is denied adequate power to meet renewed consumer and mortgage credit inflation if it should develop in the future. ${ }^{21}$ Finally, we have yet to take effective action to restrict non-essential spending by business and government. This is true not because we are unable to distinguish between the indispensable and the desirable in capital formation, but because the government has thus far been unable to muster the public support required to put such unpleasant decisions into effect.

Indirect controls are essential to reduce the pressure of excess demand on the market and, if the size of the defense program is relatively small as compared with the total productive power of the economy, they may be sufficiently effective for limited periods to permit some or all prices to be stabilized by the impersonal forces of the market. But to place exclusive reliance on indirect controls and, in the midst of mobilization, to abandon direct controls and dismantle the laboriously constructed government apparatus required to administer them is surely to invite catastrophe.

This does not mean, however, that comprehensive price controls and hold-the-line price policies are equally appropriate in rearmament and in war. Temporary emergencies may develop in a defense economy which require the full use of the Government's authority over prices and wages, and the mere existence of power in the Government will help to prevent speculative and panic movements. But these are persuasive considerations for preserving the authority to control prices and wages and using them as needed, not reasons for making a wartime system of controls a fixture of the Nation's economy for an indefinite period of time.

21. JoHnston, op. cit. sipra note 20 , at 14 . 
At the end of 1951 some products in ample supply, under price control, were selling well below their maximum price regulations. In his final report Mr. Johnston, the ESA Administrator, stated that although direct controls should be under constant review "to determine when any or all of them can safely be removed," it was premature then to recommend decontrol for these reasons :

"Severe limitations being placed through allocations authority on the output of many consumer durables will inevitably exert renewed price pressures in important areas of the economy.

"Shortages in hard goods, coupled with greater consumer purchasing power, will be reflected in increased demands for items now in ample supply at below-ceiling prices. No one is being hurt by controls on products selling today below ceilings and we have insurance to protect us against future inflationary blows." ${ }^{22}$

So long as the defense program is not yet over the first hump, these arguments have very substantial validity. Mr. Wilson has just reported that in 1952 "The inflationary outlook is still dominated by the continuing rise in defense expenditures." 23 Nevertheless the fact remains that even now the inflationary danger is not equally great for all items. The hard question is whether direct controls should be maintained on products in demonstrably abundant supply.

In the making of public law and stabilization policy for a vigilance economy there are few experts, for there has been little pertinent experience. The Government has only just begun to grapple with the difficulties so that whoever speaks, particularly the private observer who may be unaware of considerations which bind the official policymaker, should speak with humility. As yet, beyond the obvious, only cautionary guidance is justified.

The free market system is certainly the most efficient and least burdensome system yet devised for the distribution of our resources and production; it should be fully and completely restored as soon as our economic defenses are strong enough and our civilian supply situation warrants it. Since, characteristically, the inflationary pressures of a defense economy are changeable, we must decide whether it is wise or possible to develop the means to turn price controls on and off as needed. If some prices are pushing against ceiling regulations and others are fluctuating below them, must a system of comprehensive controls be maintained or can we devise a secure plan of "triggereddecontrol"?

22. JoHNSTON, op. cit. supra note 20 , at 25 .

23. Director of Defense Mobilization, Fourth Quarterly Report to the President 5 (January 1, 1952). 
In the initial effort to achieve stability, price control by broad measures such as GCPR and the General Maximum Price Regulation of OPA is essential to stop the upward thrust of all prices, to restore public confidence, and to give the Government time in which to put into effect the tailored regulations which both equity and defensetype production patterns demand. In wartime a fully developed system of controls may be necessary because heavy inflationary pressures operate continuously throughout the economy. In a more limited emergency, at times, some ceilings will be left stranded at levels above the free market prices. The Government then has the choice of leaving the regulations at their existing levels as a form of insurance against renewed price pressures, revising them downward as markets fall, or ordering decontrol because free market forces are operating.

The indefinite preservation of umbrella ceilings against the possibility of future inflationary storms is an appealing metaphor but probably bad policy. The levels of prices which are embodied in such regulations, and their relationships to other prices, will have only the most random bearing on the pattern of consumer or defense demand which exists when the storm breaks. The overriding merit of the Baruch ceiling is that it seizes and for a period preserves price levels and relationships fixed by the demand requirements of a free market. To rely on umbrella ceilings for possible future periods of stress, would be to attempt to satisfy the needs of a later crisis by solutions devised for an earlier one. To revise constantly so that ceiling regulations chase prices rather than control them would seem to be unnecessary rather than positively harmful. 'When prices are set by the forces of a free market rather than the limitations of a ceiling, and this condition is likely to continue, special justification is needed to warrant continued regulation by direct controls. There may, of course, be some normally stable prices so threatened that umbrella ceilings would be appropriate; there may be others important and volatile enough to justify constant revisions of the ceiling regulations. But the burden of proof in such cases is on those who resist decontrol. If free market forces are operating and if the available supply appears to be adequate for a substantial period ahead, the apparent solution in a defense economy, for industrial prices, at least, is to order decontrol. The dangers, however, must be reckoned with in each case.

One danger of selective decontrol is that as free markets grow and become more profitable-and each decontrol order will intensify the demand for others-they may consume abnormal quantities of scarce goods and services to the detriment of essential civilian and defense supply programs. More difficult to deal with is the possibility 
that price control for some and freedom for others may arouse the resentment of those who are kept subject to controls. Whether a widespread sense of grievance and injustice would in fact develop and become a serious obstacle to a system of selective price controls is partly a problem in social psychology and partly a question of how the controls are administered. A related problem in equity is whether labor would be willing to accept continued regulation of wages, assuming the need existed, if important areas of prices were released from controls. The answer would probably turn on what happened to the cost-of-living and to business profits. If the cost-of-living were stabilized the value of earnings would be preserved; but if business profits increased substantially as a consequence of decontrol, labor leaders would be quick to point out that the essential balance among major economic groups was being destroyed. Nevertheless, in a defense economy, price and wage stabilization should not be regarded as so intertwined that both must be invoked if only one is needed. Rather, they should be viewed as independent measures which require independent justification. There is no need as yet to assume that labor will demand de jure control of substantially all prices as a condition of continued acceptance of wage stabilization, when offered assurances of de facto stability in living costs and profits. The first question is whether the assurances can be given, not whether the offer would be accepted.

In selecting the initial items and services for testing the possibilities of decontrol, consideration should be given to those which least influence the cost of living, those which are unlikely to compete for manpower and essential materials with other more important civilian and defense items, and to those which are likely to remain in relatively abundant supply. In the search for other criteria for decontrol we might also consider the British example and release luxury or semiluxury products on which large excise or purchase taxes exist or are imposed.

If decontrol is extended to all items, or essential defense items, or items which are important in the cost of living, the price administrator must then be equipped with a mechanism for recontrol. As yet such a mechanism has not been devised. A possible approach might be to maintain a skeleton staff obligated to keep the regulations in a state of readiness should the need develop and directed to maintain contact with a reserve corps of price experts available for active duty on short notice. The idea is attractive but the administrative difficulties appear to be almost insuperable. Yet dogmatic judgments should be avoided. The proper course may be to decontrol non-essential items 
on a selective basis as their prices become clearly responsive to free market forces, and then, in limited but more important areas, to experiment with stand-by regulations and cadres of price experts to determine whether conditional recruitment is possible and whether adequate public and Congressional support can be obtained for a readiness program of price controls.

To determine what prices should be controlled in a defense economy is difficult, but to formulate lasting standards for setting the levels of prices and for adjusting them is far more difficult. Frozen prices in our country are intolerable for more than brief intervals. Product alterations required by changing seasons, styles and materials, as well as price adjustments offered as incentives or forced by increáses in uncontrolled costs (for example, foreign transportation, imports and overtime labor) prevent price rigidity. Even our wartime stabilization policy recognized the need for some increases and sought only to limit the number of adjustments and to insure the maximum of cost absorption.

For the crucial period of war, limited as it is in time, there is no safe alternative, under a system of direct price and wage controls, to a strict hold-the-line policy; the political and economic limitations of taxation and other indirect controls, in any grave future emergency, would be far too confining to be relied on as exclusive weapons against the heavy inflationary pressures of all-out industrial mobilization. In war, all prices are vulnerable and all price movements at least symbolically significant; change, growth, and flexibility in production become secondary to the over-riding need for economic stability, securely controlled. For a defense economy of the present magnitude, however, such an intractable, unyielding policy is unacceptable and may be harmful. The maintenance, expansion and modernization of business facilities, financed by earnings, and the readiness to produce what people want rather than what the profit incentives of frozen prices dictate, is the long run foundation of our economic strength. In the present limited emergency of unlimited duration, which we assume will divert for defense a relatively small fraction of the Nation's product, this foundation must be preserved. That it can be preserved without insulating profits from every increase in the cost of labor or materials is evident. The growth in productivity over the years has made possible a substantial advance in wages relative to prices while at the same time insuring a satisfactory volume of profits. The present levels of profits, partly the result of post-Korean price increases and partly of a higher rate of business operations, insure the availability of a cushion in most industries against the impact of reasonable wage 
demands. For new commodities and new sellers, however, special consideration may be necessary. This will weaken the controls and provide loopholes for the unscrupulous, but the alternative is to limit, or deny, for an indefinite period, the opportunity for development and change.

Although flexibility in the control of business prices is thus necessary and desirable in a defense economy, there is danger that we may be persuaded to accept the form of controls without insisting on their substance. Cost absorption is the essential element of any system of price control which purports to do more than validate rising prices. Every system of price control involves the recognition of some cost increases; more flexible systems involve the recognition of more cost increases. The question is at what point flexibility-which in this context merely means higher prices in response to higher costs-becomes legalized inflation.

In a persuasively written statement on price and wage controls the Research and Policy Committee of the Committee for Economic Development recently proposed a flexible system of direct controls, under which business price ceilings could be recalculated every three months to reflect increases or decreases in the costs of component goods and services bought in some base period. Under this system each seller would make his own recalculations on the basis of his own index of costs for each of his products under control. If cost factors were available on an industry-wide basis, the Government would announce the adjustment factor and the seller would then recompute his ceiling by applying the factor. In the case of standardized products, the Government might itself announce the ceiling price quarterly.

The CED approach is responsible, and the entire statement should be read by any student of the subject. To those who have seen price control operations at first hand, however, a major difficulty, probably a fatal defect, is evident. The system is substantially unenforceable. The cooperation of buyers could not be enlisted in securing compliance since legal prices would vary from seller to seller and would be recalculated by each seller, except in limited areas of standardized or near standardized products. It is a fair prophecy that, under such a system, there would be fewer such standardized products than now. More important, the control agency, whose function is described as "largely that of an auditor with enforcement powers," would be faced with the gigantic task of recruiting and organizing as many thousands of auditors as the Congress would authorize to be hired from an already overburdened accounting profession. The CED correctly recognizes that enforcement, under this system, would require expert 
accountants; their job would be to check, so long as controls are maintained, the innumerable and complex cost computations of several million sellers of controlled commodities. This is apart from the very great complexities of overhead allocation-which would be aggravated by the decontrol of some products.

The Capehart Amendment, contained in Section 402(d) (4) of the amended Defense Production Act, has properly been criticized for its requirement that increases in "all" costs between Korea and July 26,1951 , shall be allowable in unit prices of manufactured and processed goods. It thus directs that the principle of cost absorption be ignored for a thirteen month period. But the main difficulties with the Amendment are administrative; there is no clear way of measuring and allocating all costs to each unit of material, and there is no feasible way in which the price control agency can check so complex a mass of figures. The CED proposal is less arbitrary-it calls only for the recognition, quarterly, of all "major" items of direct and indirect costs -but it is unfortunately subject to many of the other objections leveled against the Capehart Amendment.

\section{IX}

The system of price and wage control in effect today, which the CED program was designed to supersede, can hardly be described as a closely geared, symmetrical product of economic engineering. ${ }^{24}$

In wage stabilization the cost of living is the basic guide although limited increases are also permitted to correct inequities, to operate merit systems, to establish health and welfare plans, and as incentives for the recruitment of workers into defense industries. Increases for the payment of pensions, and to compensate workers for the growth in productivity are under consideration.

In stabilizing farm prices parity is the determining factor; prices below parity (or certain higher minimum standards) are not subject to control.

Industrial prices are usually fixed on the basis of pre-Korea unit prices adjusted for subsequent cost increases, with provisions for relief (i) for an entire industry if profits fall below the industry earnings standard; (ii) for a particular product line if profits on that line fall below the break-even point; (iii) for an individual firm if it is in a loss position. Price increases may also

24. Director of Defense Mobilization, op. cit. supra note 23, 37-44. See J. K Galbraith, "The Disequilibrium System," American Economic Review, Vol. 37, No. 3 , June 1947, pp. 287-302. The reference to "disequilibrium" in the title to Mr. Galbraith's article refers to the excess of demand over supply which existed and was nurtured in our economic organization during World War II. 
be granted if necessary to obtain increased production of essential materials.

Distributors, under the Herlong Amendment (Section 402(k) of the amended Defense Production Act), in all regulations issued after the 1951 amendments, are guaranteed "their customary percentage margins" on invoice costs regardless of operating costs or profits.

In addition, most prices are subject to some pressures because not all costs are controlled; some prices may rise beyond existing levels because of the Capehart Amendment; meat regulations cannot lawfully be supported by the assignment of slaughter. quotas to insure that cattle marketings are kept within normal channels.

Under this system of direct controls, assisted by some increased taxation, limited credit controls, voluntary savings, and a strikingly modest degree of curtailment of non-essential investments, wholesale prices since the spring of 1951 have remained relatively stable, although living costs have increased $2.6 \%$ since the issuance of GCPR. By the pragmatic test, therefore, this curious patchwork program-which in many essentials resembles the World War II program-has been effective enough. For the time being, moreover, no major group in the population seems to be so discontented with its members' share of the Nation's production that it is seeking to destroy the precarious balance which the system provides. If the wage-price problem in the steel industry is settled within the framework of existing wage standards, and inflationary pressures do not substantially increase, the mobilization program may pass the first hump without a great deal of additional strain and with only a few refinements. If inflationary pressures increase markedly, however, or if unhappily our defense economy becomes a war economy, we shall almost certainly be obliged to develop new and as yet untried solutions for the new problems.

In a time of all-out war some form of the Baruch Plan, with its balanced emphasis on heavy taxation and other indirect controls, together with firm and comprehensive price, wage and other cost controls, would undoubtedly become our first major economic defense line. But one world war and one police action have left their mark in our laws and in our habits. We have become too knowing in the ways of avoiding unpleasant and difficult tasks. We have become too wise in the ways of shifting economic burdens to others. Our statutes and our stabilization policies are barnacled with special exceptions and limitations. In the limited emergency, which so much resembles a peacetime economy, these may be tolerated; for full mobilization or 
World War III they would have been cleaned away. We cannot assume, we may only hope, that each of the major economic groups would be willing at that time to give up what it has so laboriously won in the inter-group competition for a greater share of the Nation's product. We must be prepared, therefore, in the event that the regeneration will not be complete: that taxes cannot be increased fast enough; that credit controls cannot be strengthened soon enough; that voluntary savings will not suffice to prevent the excess of demand over supply which leads to spiraling inflation. It may then be necessary to develop new techniques to reduce consumer demand as part of a larger stabilization framework. Of these new techniques the most hopeful appears to be a controlled savings program which would oblige us to devote a part of our incomes, on some progressive scale, to the purchase of Government securities. It may be desirable to exclude from taxable income the sums required for savings; it may be wise, beyond this, to tie the securities to the cost-of-living so as to guarantee that the value of the savings will be preserved. ${ }^{25}$

Mandatory savings, however, is only one possible alternative; there may be others. ${ }^{26}$ What is clear now is that all of the alternatives must be examined promptly and probably cannot support inflationary pressures much beyond those which presently prevail.

25. Kooperativ Forbundet, the quasi-public Swedish Cooperative, has recently offered a 20 -year $3 \%$ bond issue which will be paid off at maturity at a rate to be determined by the then existing price level, as measured by the cost-of-living indexes compiled by the Swedish Board of Social Welfare. If held to maturity the bonds in no case will be paid off at less than $100 \%$ of their face value, nor higher than $150 \%$. The Wall -Street Journal, January 17, 1952. See also a series of four articles entitled Agenda for the Age of Inflation, The Economist, Aug. 18, 25, Sep. 1, 8 '(London).

26. A far more drastic approach to the problem of reducing excessive consumer demand is expenditure rationing. This would place a ceiling on the total amount which each consumer unit may spend during specified periods for consumer goods and services. The consumer would retain discretion to decide what items to buy, so long as his total purchases do not exceed his available funds. In their fully developed form controls of this kind are so drastic that they cannot seriously be considered in our country for crises much short of all-out atomic warfare. See ScITovsky, SHAW and Tarshis, Mobilizing Resources for War (1951). 